\title{
Taxonomic revision of the freshwater cyanobacterium „Phormidium“ murrayi = Wilmottia murrayi
}

\author{
Otakar StruneckÝ，Josef Elster \& Jiř́i KOMÁREK \\ Institute of Botany, Academy of Science of the Czech Republic, Dukelská 135, Třebon̆ \\ Faculty of Science, University of South Bohemia, Branišovská 35, České Budějovice, Czech Republic
}

\begin{abstract}
The cyanobacterial genus Phormidium is polyphyletic, as follows from recent molecular and phenotypic analyses. Several isolated clusters were found also in Antarctic populations (TATON et al. 2006, TATON et al. 2010, StRunecKÝ et al. 2010b). A few of them have already been described or revised on the generic level (e.g., Phormidesmis, Microcoleus). One of the separate clusters belongs to a group of strains identified traditionally as Phormidium murrayi, described from the Antarctica originally in 1911 as Lyngbya murrayi by W. et G.S.WEST. We evaluated 23 morphologically similar strains or populations resembling Ph. murrayi from the Antarctica and few other geographical regions; 6 of them were studied by us by molecular methods. Morphological characteristics and $16 \mathrm{~S}$ rDNA similarity corresponding with typical $P h$. murrayi were shared mostly by the specimens from the Antarctica. Molecular analyses confirmed that Ph. murrayi represents a special taxonomic group (on the generic level) inhabiting commonly shallow freshwater classified as a special genus in cyanobacterial taxonomy (Wilmottia gen. nov.) according to the recent "polyphasic approach". The type species of Wilmottia, W. murrayi, was determined up to now to be characteristic for the Antarctica. Other phylogenetically and morphologically similar types from other regions represent possibly different taxa (species) of the same generic unit. The specific status of similar or related strains from other regions should be therefore solved in the future.
\end{abstract}

Key words: cyanobacteria, Phormidium, polyphasic taxonomy, ecology, Antarctica

\section{Introduction}

The traditional genus Phormidium KÜTZING ex GOMONT 1892 is polyphyletic, as follows from recent molecular analyses (TATON et al. 2006; Marquardt \& Palinska 2007; Palinska \& Marquardt 2008; StruneckÝ et al. 2010 a,b), as well as from detailed cytomorphological investigations (e.g., TURICCHIA et al. 2009). Several phenotypically distinct clusters were also characterized during the study of Antarctic cyanobacterial populations (TATON et al. 2006, 2010; Comte et al. 2007; STRUNECKÝ et al. 2010a), the isolated position of which in phylogenetic trees was confirmed. To such separated clusters belong also group of strains identified traditionally as Phormidium murrayi, described originally from the Antarctica by W. et G.S.WeST in 1911 as Lyngbya murrayi. Similar types ("Phormidium murrayi") evaluated by molecular methods in previous studies (TATON et al. 2006; STRUNECKÝ et al. 2010b) represented also always a special, isolated cluster of simple trichal cyanobacterial morphospecies.

We studied 23 morphologically similar strains isolated from Antarctic localities (6 supported by molecular sequencing) and compared them with the corresponding literature. Based on a polyphasic evaluation, which combines genotypic (16S rRNA gene sequencing) and phenotypic (morphological analysis, ultrastructural sections) methods, a special cluster was isolated, which must be separated from the traditional genus Phormidium (Geitler 1932; Anagnostidis \& KomÁreK 1988; KomÁreK \& ANAGNostidis 2005). In our paper a new genus is classified as Wilmottia gen. novum. Comparison with literature sources (BOYER et al. 2002; Š ABACKÁ 2004; CASAMATTA et al. 2005; TAton et al. 2006; Сомte et al. 2007; LoKmer 2007, Wood et al. 2009; Heath et al. 2010; StRUNECKÝ et al. 2010b) supported this taxonomic transfer. 


\section{Methods}

Sampling sites and strain preparation. The list of strains and literary data are presented in Table 1. Phormidium specimens were collected from various localities of Antarctic habitat types (Fig. 1). Samples were transported frozen to the laboratory. A small quantity of each sample was placed on a Petri dish with agar (solid medium with $1.5 \%$ agar containing the mineral nutrient medium BG-11; RIPPKA et al. 1979). The dilution plate method was used for isolation and culturing of cyanobacteria (ELSTER et al. 1999). This method was repeated several times to obtain isolated unialgal strain colonies. The Petri dishes were placed in an illuminated refrigerator $(90$ $\mu \mathrm{mol} . \mathrm{m}^{-2} \cdot \mathrm{s}^{-1}=$ cca $20 \mathrm{~W} . \mathrm{m}^{-2} \mathrm{PAR}$, temperature 5 to $8{ }^{\circ} \mathrm{C}$ ) with a light regime of $18 \mathrm{~h}$ of white fluorescent light, $2 \mathrm{~h}$ of UV-B radiation, and $4 \mathrm{~h}$ of darkness. Germicidal lamps sterilized the cultivation box repeatedly (UV-B radiation did not penetrate through the glass dish). After a few days of cultivation, visible colonies of Phormidium were observed and separately transferred to sterile agar tubes. Subsequently, pure strains (unialgal with low bacterial contamination) were cultured at a temperature of $6{ }^{\circ} \mathrm{C}$ and light of $30 \mu \mathrm{mol} \cdot \mathrm{m}^{-2} \cdot \mathrm{s}^{1}$. In addition to these newly isolated strains, strains originating from CCALA (Culture collection of Algae at the Laboratory of Algology, Třeboň, Czech Republic - http://www.butbn.cas.cz/ ccala) with previously sequenced and published $16 \mathrm{~S}$ rRNA genes (CCALA 852, CCALA 843; STRUNECKÝ et al. 2010a), and sequences from GenBank (Ant-Ph58, Comte et al. 2007; ANT.ACEV5.2, TATON et al. 2006; B-Tom, LoKmer 2007; CYN38, CYN39, Wood et al. 2009, HEATH et al. 2010), were compared and used for phylogenetic analyses. All new isolated strains were allocated to the CCALA. The cultivated strains were identified according to ANAGNOSTIDIS \& KomÁreK (1988) and KomÁreK \& ANAgnostidis (2005). Strain morphologies were analyzed using an Olympus BC51 light microscope up to $1000 \mathrm{x}$ magnification. Photomicrographs were taken with an Olympus DP71 Camera, equipped with Quick Photo Micro software.

Molecular analyses. DNA from the unialgal strains was extracted using the modified method of YILMAZ et al. (2009). The available amount of cultivated cells was suspended in $50 \mu$ l of TE buffer at $\mathrm{pH} 7.4$. and 750 $\mu \mathrm{l}$ of XS buffer ( $1 \%$ potassium ethyl xanthogenate; 100 mM Tris-HCl, pH 7.4; 20 mM EDTA, pH 8; 800 $\mathrm{mM}$ amonium acetate and $1 \%$ SDS) in an eppendorf tube with glass beads. The trichomes were manually crushed by a micropestle. Tubes were incubated for 2 $\mathrm{h}$ at $70^{\circ} \mathrm{C}$. After incubation, the tubes were vortexed for $30 \mathrm{~s}$ and frozen at $-70{ }^{\circ} \mathrm{C}$ for $30 \mathrm{~min}$. The sample was thawed and shaken for $15 \mathrm{~min}$, centrifuged for 20 $\min$ at $15,000 \mathrm{~g}$ and the supernatant was transferred to a clean microcentrifuge tube. The DNA was precipitated overnight in a $2: 3$ volume of $100 \%$ ethanol with the addition of 1:20 volume of Sodium Acetate ( $3 \mathrm{M}$, $\mathrm{pH}$ 5.2) followed by centrifugation for $30 \mathrm{~min}$ at $15,000 \mathrm{~g}$. The supernatant was discarded and the pellet was washed with $100 \mu \mathrm{l}$ of $70 \%$ ethanol followed by centrifugation for $15 \mathrm{~min}$. After discarding the supernatant, the pellet was dried and dissolved in 100 $\mu l$ of miliQ water.

The 16SrRNAgenewith the 16S-23Sintergenetic segment was amplified using the primers 359F (GGGGAATYTTCCGCAATGGG (NüBEL et al. 1997), and 23S30R (CTTCGCCTCTGTGTGCCTAGGT) (WiLmotte et al. 1993) with the following settings: a starting denaturation step $\left(94{ }^{\circ} \mathrm{C}, 5 \mathrm{~min}\right) ; 40$ cycles of $30 \mathrm{~s}$ at $94{ }^{\circ} \mathrm{C}, 30 \mathrm{~s}$ at $55^{\circ} \mathrm{C}$, and 3 minutes at 72 ${ }^{\circ} \mathrm{C}$; final extension for 7 minutes at $72{ }^{\circ} \mathrm{C}$ and cooling to $4{ }^{\circ} \mathrm{C}$. A successful PCR was confirmed by running a sub-sample on a $1 \%$ agarose gel stained with ethidium bromide. PCR products were purified using a QIAquick PCR Purification Kit (QIAgen, Germany). Sequencing of the $16 \mathrm{~S}$ rRNA gene fragment was performed on an ABI 3100 sequencer, using BD3.1 (Applied Biosystems, Foster City, USA) chemistry, with six primers (27F, 23S30R, CYA 810RGTTATGGTCCAGCAAAGCGCCTTCGCCA, CYA783F-TGGGATTAGATACCCCAGTAGTC (STRUNECKÝ et al. 2010b), S17*_GGCTACCTTGTTACGAC and ILE23F- ATTAGCTCAGGTGGTTAG (Wilmotte \& Herdman 2001) to obtain complementary sequences. For examining the molecular phylogeny, 11 sequenced strains were combined with strains studied by previous authors (Table 1).

Phylogenetic analyses. Sequences were aligned in MAFFT (mafft.cbrc.jp) (КАтон \& ТоH 2010) considering secondary structure and minor changes were done manually with BioEdit 7.0.1 (HALL 1999). For the phylogenetic analysis, a fragment of $1097 \mathrm{nt}$ was used (corresponding to E. coli ATCC $1177516 \mathrm{~S}$ rRNA residues 302-1,412) except of the New Zealand strains CYN38 and CYN39. Phylogenetic analysis was conducted in Mega 4 (TAMURA et al. 2007) using the Maximum Likelihood method under the JukesCantor method with uniform rates among sites. Topology vas validated by Maximum parsimony under Close-Neighbor-Interchange method in Mega 4 and Bayesian analysis in MrBayes 3.1.2. (HuELSENBECK \& RoNQUisT 2001) at metacentrum.cz. For the Bayesian analysis, two runs of four Markov chains over 8000 000 generations, sampling every 100 generations, were employed. The initial 20000 generations were discarded as burn-in. Sequences for comparison of $W$. murrayi were chosen under extensive evaluation of more than 1100 sequences of oscillatorialean cyanobacteria available in GenBank (www.ncbi. nlm.nih.gov) and Ribosomal database project (rdp. cme.msu.edu) (unpublished). For a synoptic view 


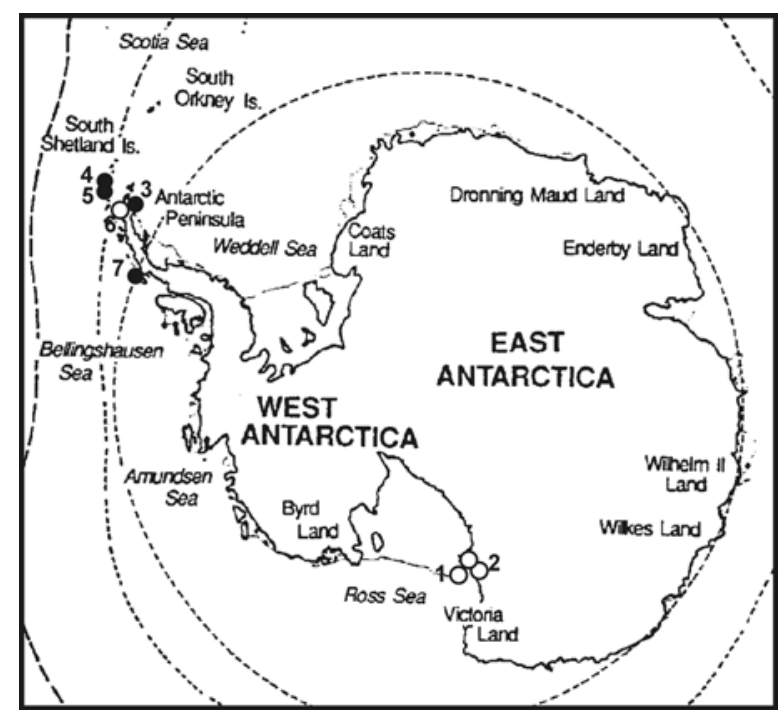

Fig. 1. Confirmed localities of Wilmottia murrayi in the Antarctica (black points); in all localities were collected samples and isolated strains from several sites. Localities (selected from literature are marked by circles): (1) Ross Island; (2) vicinity of McMurdo station; (3) James Ross Island; (4) King George Island - Admiralty Bay; (5) King George Island - Jubany; (6) Cierva Point; (7) Adelaide Island (Map of Antarctica modified according to STONEHOUSE 1989).

of phylogenetic tree only the sequences designated mostly as Phormidium-like cyanobacteria available from culture collection were chosen as specimens to the presented phylogenetic tree. Sequence identity matrix was calculated from the alignment in BioEdit (HALl 1999) from all positions including gaps.

Ultrastructure. For the ultrastructural studies, biological material of strains were fixed with $6 \%$ glutaraldehyde and kept in this solution for several days at room temperature. After that, samples were washed with $0.05 \mathrm{M}$ phosphate buffer $(\mathrm{pH}$ 7.2) and postfixed with $2 \%$ osmium tetroxide in the same buffer for 2 hours at room temperature. After washing with $0.05 \mathrm{M}$ phosphate buffer, the cells were dehydrated with a graded isopropanol series and embedded in Spurr's resin (SPURR 1969) using propylene oxide as an intermediate stage. Thin sections were stained with uranyl acetate and lead citrate and observed in a Jeol JEN 1010 transmission electron microscope at $80 \mathrm{kV}$.

\section{Results}

\section{Genotypic characters}

Strains identified as "Phormidium murrayi" and analysed by $16 \mathrm{~S}$ rRNA gene sequencing from Antarctic habitats form a concise separated cluster. This result confirms the previous published studies (TAton et al. 2006; Strunecký et al. 2010). The genetic similarity between 11 strains, identified or as "Phormidium murrayi", or "Microcoleus glaciei” was 98-100\% (Fig. 2; Table 2B). Similar types to "Ph. murrayi" isolated from other habitats and from localities outside Antarctica (strains B-Tom from Brazil - LoKMER 2007; strains CYN 38 and CYN 39 from New Zealand - Wood et al. 2009, HeAth et al. 2010) belong to the same clade (Fig. 2). However the sequences of the New Zealand strains of Phormidium murrayi were available only in a 659 bp fragment that was approximately one-half the length of the sequences from this study. Therefore, the Antarctic "Ph. murrayi" represents a special unique taxon, distinct from other cyanobacterial clades by always more than $7.1 \%$ and representing therefore a special generic taxon, well separable from the genus Phormidium. The strains from Brazil and New Zealand (B-Tom, CYN38, CYN39) could be probably considered as special species from the same generic unit, separating also ecologically and phytogeographically from the Antarctic populations.

We have constructed large amount of phylogenetic trees from more than 1100 sequences of oscillatorialean cyanobacteria as starting point by various methods (unpublished). Geitlerinema came close to $W$. murrayi in the most cases hence we propose that Geitlerinema is the most related taxon to the new genus. The positions of both generic entities in the phylogenetic tree and also other markers (ultrastructure) indicate the classification of these genera rather in the vicinity of pseudanabaenacean cyanobacteria than to the cluster of the phormidiacean clade. Our results are also in agreement with autapomorphic morphological features (Wilmottia was sooner classified into the genera Phormidium and Microcoleus, i.e., distant from Geitlerinema and from Pseudanabaenaceae). Value of $70 \%$ in the bootstrap could have been considered as low, however under the current availability of related sequences in nucleotide databases we consider it sufficiently high for our statement and separation of Wilmottia from Geitlerinema.

\section{Phenotypic characters}

All strains included in the Antarctic cluster " $P h$. murrayi" have more or less the same morphology, which is distant from typical Phormidium (based on the type species P. lucidum) and Microcoleus (based on $M$. vaginatus), and can serve to characterize this taxon on the generic level. 


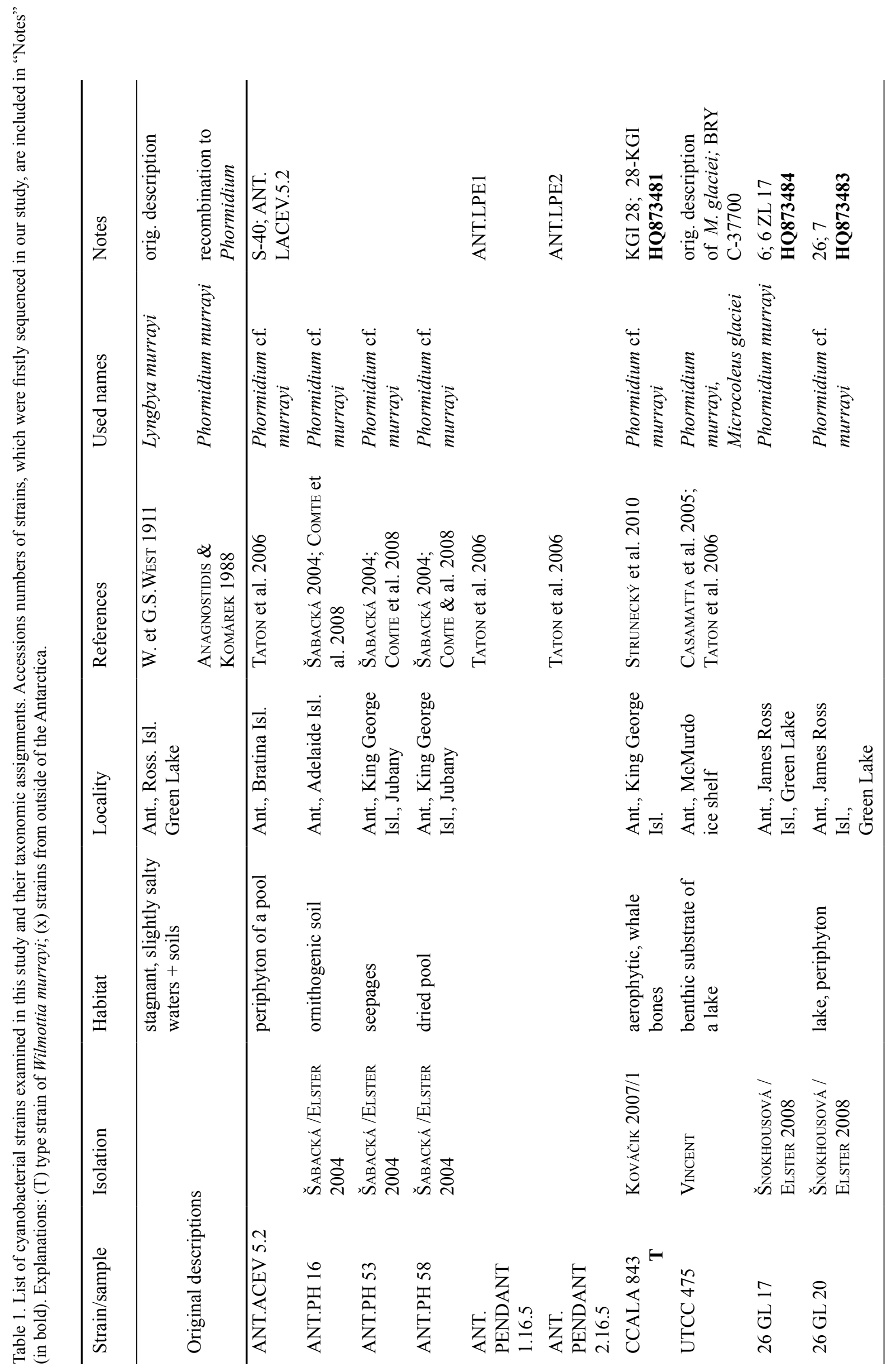




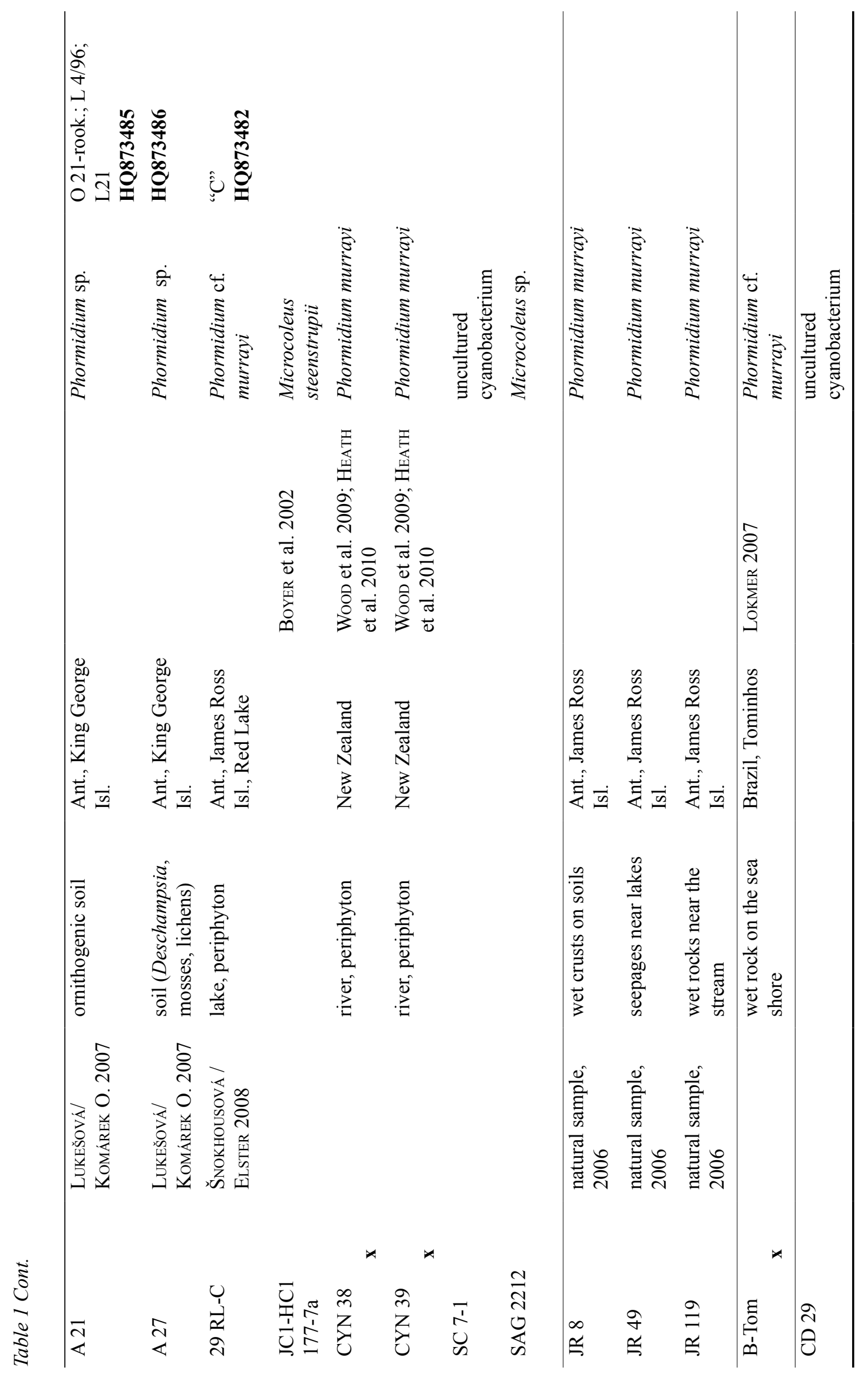


Filaments are solitary or with several to many trichomes associated parallely (in fascicles), without common firm sheaths, but enveloped by wide, colorless, unlamellated, diffluent slime. The tendency to form fascicles enveloped by common slime occurs in all populations. Trichomes are simple, cylindrical along the whole length (up to the end), uniseriate, pale blue-green, not or only slightly constricted at cross-walls, (2)3.2-6.3 $\mu \mathrm{m}$ wide. Cells are longer than wide or \pm isodiametric, end cells are rounded or slightly conical, without calyptra. All cells are capable of division (without meristematic zones). The cell content is either homogeneous or with slightly distinct peripheral chromatoplasma. Solitary granules are found in the cells, sometimes more concentrated near the cross-walls (Figs 3, 4).

\section{Ultrastructure}

The ultrastructure of cells corresponds in principle to the scheme of pseudanabaenacean cells (Fig. 5 ). The thylakoidal system is localized more or less parietally, but the parietal position is not quite regular, and sometimes the solitary thylakoids or their small fascicles pass through the central or inner part of cells. Fascicles contain 3-8 parallel thylakoids. Thylakoids are sometimes interrupted and occasionally form a triangular pattern in cross section (similarly as in several species of Geitlerinema). The solitary granules are polyphosphates, cyanophycin and carboxysomes.

\section{Formal description}

From the genetic, morphological and cytological (ultrastructural) analyses follows that the Antarctic cyanobacterium, described originally as "Lyngbya murrayi W. et G.S.WeST 1911" and designated later as "Phormidium murrayi (W. et G.S.WeST) ANAGNOSTIDIS et KOMÁREK 1988" or "Microcoleus glaciei CASAMATTA et JOHANSEN 2005", represents a special genus according to the modern criteria of cyanobacterial taxonomy. The formal taxonomic description is as follows:

\section{Description of the genus}

\section{Wilmottia gen. nov. (Figs 3-4)}

Diagnosis: Filamenta cylindrica, plus minusve recta vel paucim flexuousa, arcuata et circinata, non ramosa, solitaria vel ad multis consociata, plus minusve paralleliter in fasciculis repentes, in muco diffluenti et sine colore, aggregata; fila singularia cum vaginis facultativis, tenuis, firmis, apice apertis, non ramosis, hyalinis, incoloratis, non lamellosis. Trichoma recta vel leviter curva et flexuosa, cylindrica, ad septa non vel paucim constricta, ad apices non attenuata, 3.0-6.0 $\mu \mathrm{m}$ lata; heterocytis vel akinetis carentibus. Cellulae cylindricae, aeruginosae, saepe cum granulis sparsis sed distinctis, dispersis impletae; granula interdum ad septa transversalia agglomerata; cellulae plus minusve quadraticae vel paucim brevior vel longior quam latae; cellula apicalis cylindrica, cum cellulis vegetativis similis, terminaliter obtusa, rotundata vel oblonge-conica, sine calyptra. Thylakoides fasciculatae, praecipue parietales vel plus minusve parallelitervel paucimirregulariterdispositae. Cellulae perpendiculariter dividuntur, zonis meristematicis absentibus. Reproductio disintegratione trichomatibus in partes immobilibus, necridis carentibus. - Typus generis: Wilmottia murrayi (W. et G.S.WEST) comb. nov.

Filaments solitary or in clusters, cylindrical along the whole length, \pm straight or slightly coiled, with facultative sheath, sometimes in dense, irregular fascicles with colorless and diffluent slime, not enveloped together by a firm, wide sheath. Sheaths around single trichomes thin, \pm fine but firm, colorless, sometimes diffluent, attached to trichomes. Never falsely branched. Trichomes cylindrical, not or only very slightly (exceptionally) constricted at cross walls, not attenuated or widened towards ends, without calyptra. Cells isodiametric, rarely shortened to $1 / 2$ of their width, or up to $2 \times$ longer than wide, sometimes with different length in one and the same trichome, cylindrical, pale blue-green, usually with scattered larger granules, which are sometimesgatheredmoreatcross-walls; apicalcells cylindrical, rounded at the apex, without calyptra. Position of thylakoids in cells mostly parietal with few occasional irregularities (dependent on environmental conditions). Reproduction: Cells divide in the trichome perpendicularly by binary fission; all cells (including apical) are able to divide, without meristematic zones; disintegration of trichomes into immotile segments, without necridic cells. Phylogenetic similarity is about $90 \%$ against the Geitlerinema and $87.7-96.9 \%$ to the nearest Phormidium clusters (Fig. 2). - Type species: Wilmottia murrayi (W. et G.S.WEST) comb. nov. - Etymology: The new genus was named to honor our colleague and friend Professor AnNick Wilmotte (Liège), who has contributed substantially to the knowledge of the ecology and diversity of Antarctic cyanobacterial microflora. 
Wilmottia murrayi (W. et G.S.WeST) comb. nov.

Basionym: Lyngbya murrayi W. et G.S.West, Brit. Antarct. Exp. 1: 289, 1911.

Synonyms: Phormidium murrayi (W. et G.S.WEST) AnAGNostidis et KomÁreK, Algological Studies 50-53: 408, 1988 .

Microcoleus glaciei Casamatta, Johansen, VIs et BroAdwater, J. Phycol. 41: 432-433, 2005.

Type strain: CCALA 843 (KGI28) deposited in collections CCALA and PCC; isolated by KovÁČIK from King George Island, South Shetlands, Antarctica, 2007; accession number HQ873481.

Description: Solitary trichomes, in cluster or fine mats, blue-green or dark blue-green (on agar). Filaments solitary or several to many \pm parallely arranged, fasciculated, associated in common, colorless, very fine and diffluent slimy envelope; fascicles up to more than $50 \mu \mathrm{m}$ wide. Single trichomes have facultatively delicate, but firm, colorless, unlamellated sheaths, open at the end. Trichomes straight or slightly curved, not or only slightly constricted at cross walls, (3.1)3.6-5.4 $\mu \mathrm{m}$ wide. Cells quadratic or longer, rarely also shorter than wide, (2.6)3.4-7.2(11) $\mu \mathrm{m}$ long, pale blue-green, with homogeneous, finely granular content, usually with scattered large granules which are sometimes constricted near crosswalls; cross-walls sometimes indistinct. Terminal cells rounded at the ends. Thylakoids \pm parietal, fasciculated.

Typus (holotypus): exsiccate No. 2334HY, deposited in herbarium of Moravian Museum in Brno (BRNM); icona typica $=$ figura nostra $3 \mathrm{a}$. Other strains: see in Table 1 and Fig. 2.

Generic position: classification among pseudanabaenacean genera according to phylogenetic position, morphology of trichomes, absence of necridic cells and ultrastructure $( \pm$ parietal position of thylakoids).

Autapomorphic characters: Morphology of cells and cylindrical trichomes; fasciculation of trichomes without firmly delimited sheath, absence of necridic cells, absence of branching, ultrastructure.

Habitat: Benthic substrates in littoral of lakes, shores of glacial streams or water seepages, less frequently on wet soils usually among mosses, other algae and cyanobacteria. BROADY (2005) records "Ph. murrayi" from similar localities and also from epilithic habitats and from cryoconits.

Distribution: Known mainly from Antarctica
(Fig. 1). Strains CYN 38 and CYN 39 from New Zealand are included into the same cluster as Wilmottia murrayi, but only a fragment $659 \mathrm{bp}$ was available from both strains and their systematic position (and distribution of $W$. murrayi) must be therefore confirmed. Known localities:

- Antarctic peninsula, Cierva Point (Mataloni \& Pose 2001; Mataloni \& Tell 2002);

- Bratina Island, SW from McMurdo Station (TATON et al. 2003, 2006);

- James Ross Island, Green Lake, Red Lake; seepages below Berry Hill; (strains isol. by ELSTER); natural samples from Ulu peninsula (coll. KOMÁREK);

- McMurdo Ice Shelf (isol. by VInCEnT; in Quesada \& Vincent 1997, as Phormidium murrayi; CASAMATTA et al. 2005, as Microcoleus glaciei);

- Ross Island, Green Lake (orig. locality, locus classicus); (WEST \& WeST 1911; BROAdY \& KiBBLEWHite 1991, as "oscillatorialean morphotype J");

- South Shetlands, King George Island (Admiralty Bay) (strains isol. by LuKEŠOvÁ/O. KOMÁreK and KovÁČIK; STRUNECKÝ et al. 2010); (Jubany Station; ŠABACKÁ 2004);

- SW part of Antarctic Peninsula (Adelaide Island) near Rothera Station (Š ABACKÁ 2004; COMTE et al. 2007).

\section{Discussion}

The modern taxonomic revision and reclassification of cyanobacteria is based on the "polyphasic approach". It is a complex evaluation of cyanobacterial diversity, in which the determination of the phylogenetic position of various clades (taxa) is the first criterion for the classification process. Numerous traditional genera appeared to be heterogeneous and must be divided in different taxonomic clusters. This concerns also the genus Phormidium, in which several groups were already separated and reorganized. Usually, a difference as large as $95 \%$ in genetic similarity is considered as the limit between different genera (STACKebrandt \& Goebel 1994). It is impossible to accept strictly this limit for generic separation, because other markers (ecology, morphology autapomorphic features) must also be included into the classification criteria. However, usually a similarity of about $95 \%$ or lower indicates separation into various generic entities. 
In all taxonomic units (genera), which were separated by modern revisions were found also corresponding morphological characters that were connected with the genetic unification. Only in phenotypically very simple types (Synechococcus, Pseudanabaena, Leptolyngbya and others) is the morphological characterization difficult; the status of "cryptic" taxa (cryptic genera) is accepted for such taxonomic units. In the relatively simple traditional genus Phormidium, certain phenotypic features are recognizable, which were usually neglected or considered as variable and not important for characterization of taxa on the supraspecific level (cell width to length ratio, narrowed trichomes towards ends, absence of calyptra, absence/presence of necridic cells, constrictions at cross-walls, limits of dimensions, position of thylakoids in cells, etc.).

In the case of "Phormidium murrayi" (= Wilmottia murrayi), the group of all strains and populations corresponding morphologically to this species is unified in one phylogenetic cluster. Nearest to Wilmottia are the genera Geitlerinema and partly also Phormidesmis, Leptolyngbya and Halomicronema. However, Wilmottia is clearly separated genetically (position in phylogenetic trees) from all related oscillatorialean genera. This separate cluster, which must be considered as decisive for genetic definition is demonstrated already in TAтON et al. (2006) under the clade Phormidium murrayi. The various phenotype features can overlap slightly with few morphologically similar genera. From this point of view Wilmottia can be included in numerous other "cryptogenera" described and accepted recently as Halomicronema ABED et al., Halospirulina NÜBEL et al., Coleofasciculus SiEgesmund et al. and others. However, the autapomorphic characters of Wilmottia can discriminate it in such a degree that the phenotypic identification is also possible. Wilmottia was sooner classified to Phormidium or Microcoleus, but it is distinctly distant from these genera by morphology and size of trichomes (narrower trichomes, not attenuated trichome ends, absence of any calyptra, absence of distinct constrictions at cross-walls), and particularly by ultrastructure (parietal thylakoids). The diacritical morphological features of related fine filamentous genera (which are, however, genetically also different) are as follows:

Geitlerinema-without sheaths, motility, narrowed and sometimes morphologically distinct ends of trichomes; Phormidesmis - uniform trichomes with \pm isodiametric cells, distinct constrictions at cross-walls, firm sheaths around tight fascicles of trichomes; Trichocoleus - morphology of cells and terminal cells, morphology of sheaths, type of fasciculation; Halomicronema - absence of sheaths, smaller dimensions of trichomes, ecology; Leptolyngbya - facultative occurrence of firm sheaths around solitary trichomes, absence of fasciculation.

However, almost all these genera are heterogeneous and the cited diacritical characters concern mainly the type species. Many taxa classified into these generic clusters must be revised and numerous transfers of species between revised genera are expected.

Up to now, only one species, $W$. murrayi, should be evidently classified into the genus Wilmottia. No distinct groups were recognized among all Antarctic populations and strains included in these clusters. It concerns also the species Microcoleus glaciei, originally isolated under the name Phormidium murrayi by VINCENT (cf. Casamatta et al. 2005). The morphology of this species is quite the same as in "Lyngbya murrayi". The fasciculation of trichomes is an interesting marker, which was recognized in all strains of Wilmottia murrayi and represents probably one of the specific characters of this genus. In comparison with Microcoleus, the common mucilaginous sheath is not strictly delimited and the parallel fasciculation of trichomes is a little looser than in Microcoleus.

All confirmed strains of Wilmottia murrayi were isolated from coastal Antarctica (Fig. 1) and the ecology of this species seems to be very distinct (benthic, periphyton in lake littoral, margin of streams, watery seepages, with low temperature and long frozen periods). This genotype may occur in other regions, but, up to now, it is necessary to consider $W$. murrayi as endemic for the Antarctica. On the other hand, the genus Wilmottia can contain more species, which differ from the type also ecologically and geographically. From comparison in the GenBank, we found morphologically similar populations from Brazil (LoKMER 2007; strain B-Tom) and New Zealand (Wood et al. 2009; Heath et al. 2010; strains CYN38, CYN39), which have also slightly different ecology and can represent a special species from Wilmottia. Morphologically, several described species from the widely conceived, traditional genera Phormidium and Lyngbya are conspicuously similar to $W$. murrayi and can be 


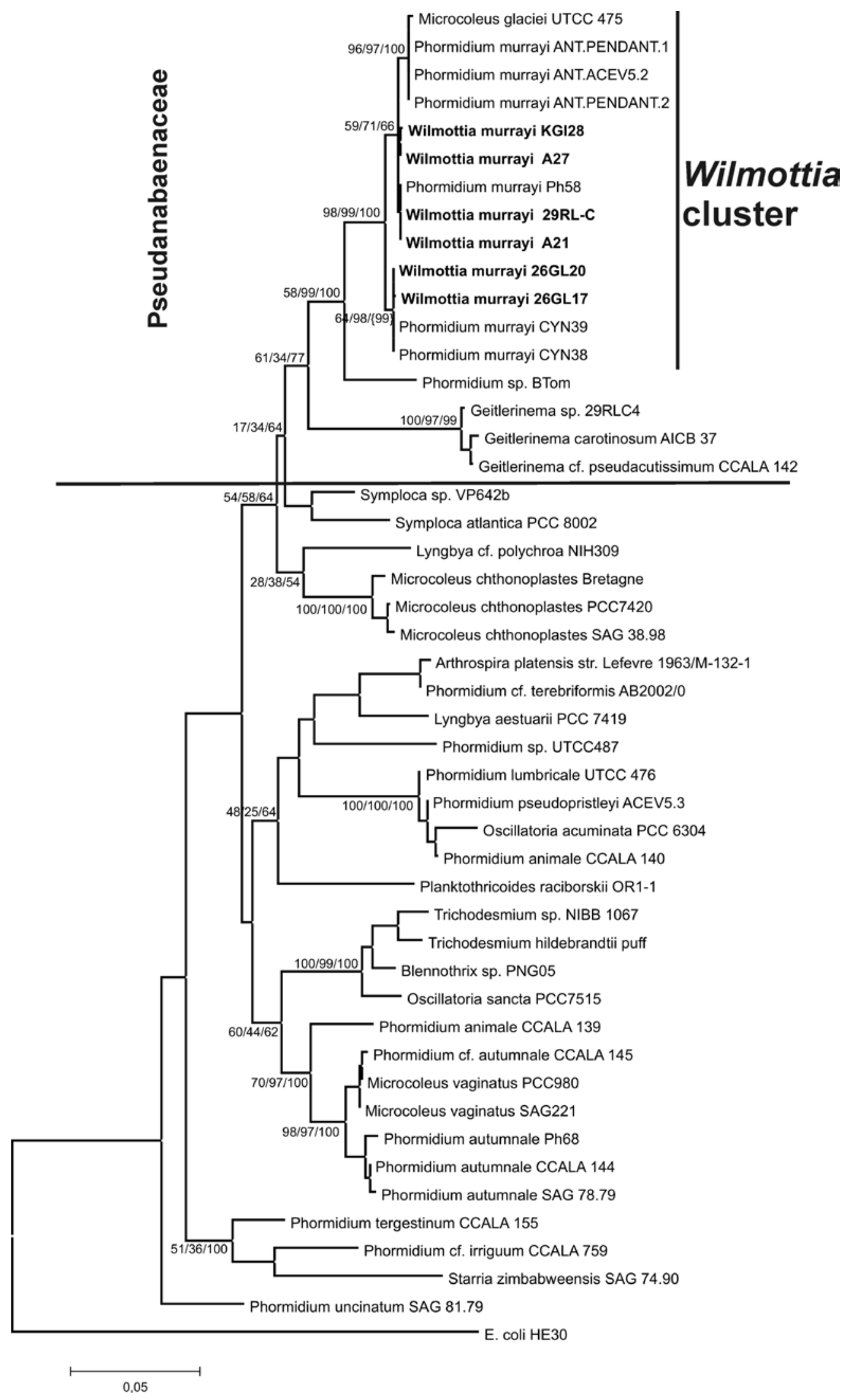

Fig. 2. Position of our Wilmottia-strains (printed by bold font) in the phylogenetic tree in comparison with other Phormidium strains, selected from GenBank. Accessions numbers of our strains see in Table 1. The evolutionary (molecular phylogenetic) analyses were conducted in MEGA4 (TAMURA et al., 2007), using the Maximum Likelihood method based on the Jukes-Cantor model [1]. The bootstrap consensus tree inferred from 1000 replicates. Values corresponding to partitions reproduced in less than $50 \%$ bootstrap replicates are not shown. 


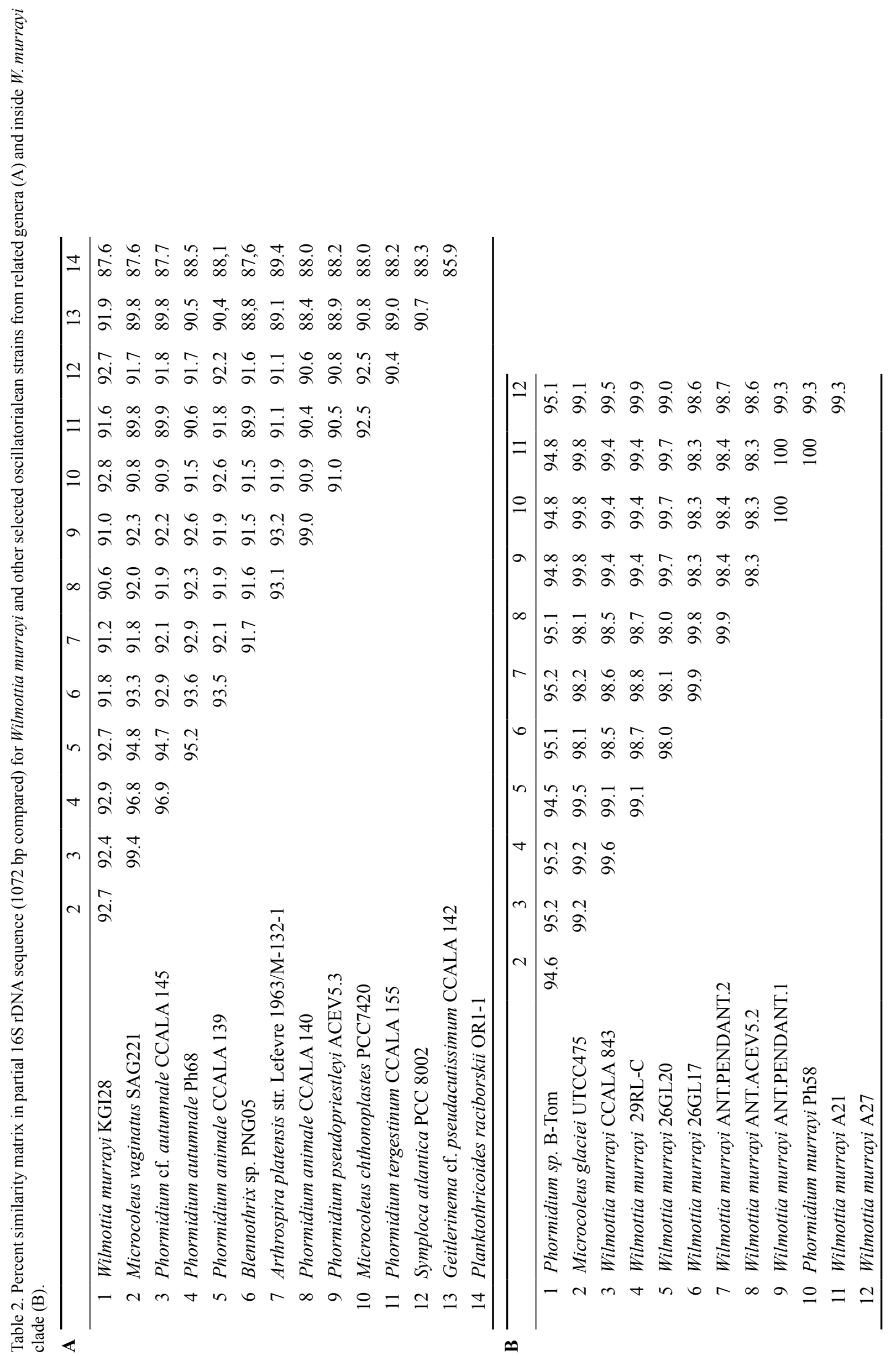



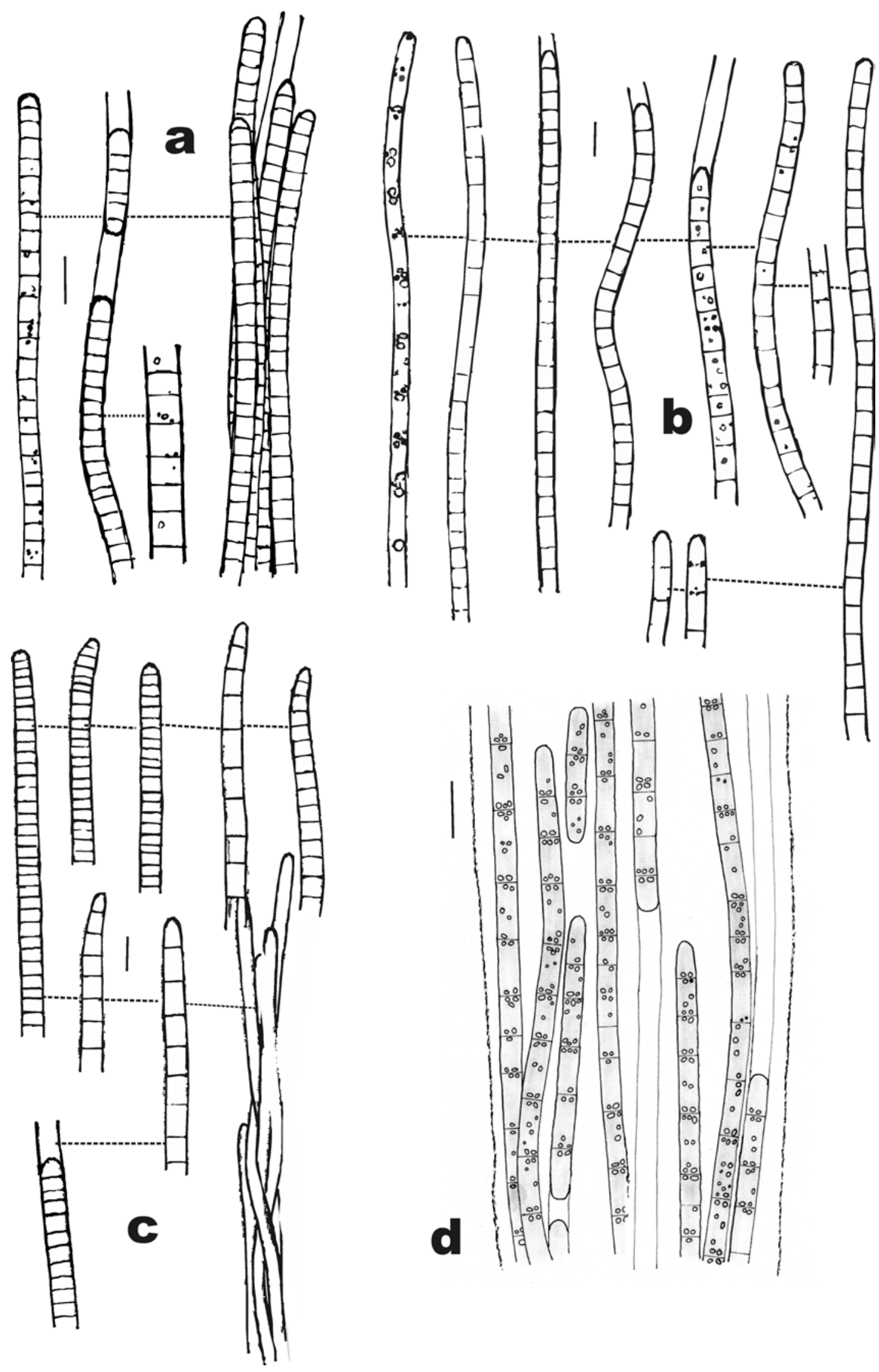

Fig. 3. Wilmottia murrayi : (a) from the type strain CCALA 843 (icona typica); (b) from littoral of small stream bellow Devils Rocks, James Ross Island; (c) from seepages near Lachman lakes, James Ross Island; (a-c) orig., (d) orig. JoHANSEN (specimen corresponding to Microcoleus glaciei, strain UTCC 475). Scale bars $10 \mu \mathrm{m}$. 

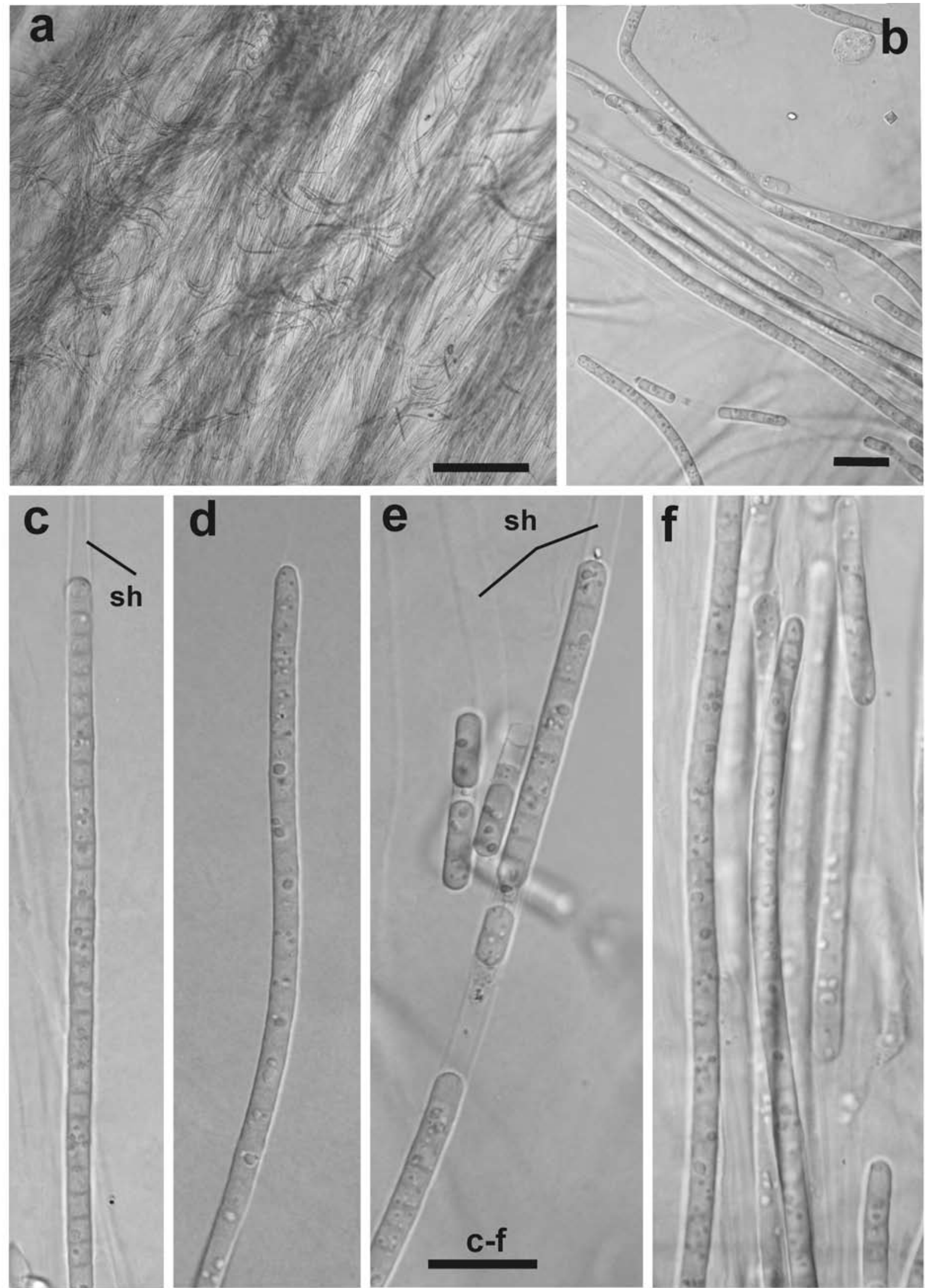

Fig. 4. Wilmottia murrayi from the type strain CCALA 843: (a-b) fasciculated growth of filaments, (c-f) details of trichomes, (e) production of hormogonia; (sh) individual sheaths around trichomes. Scale bars a $200 \mu \mathrm{m}$; b-f $20 \mu \mathrm{m}$. Orig. 

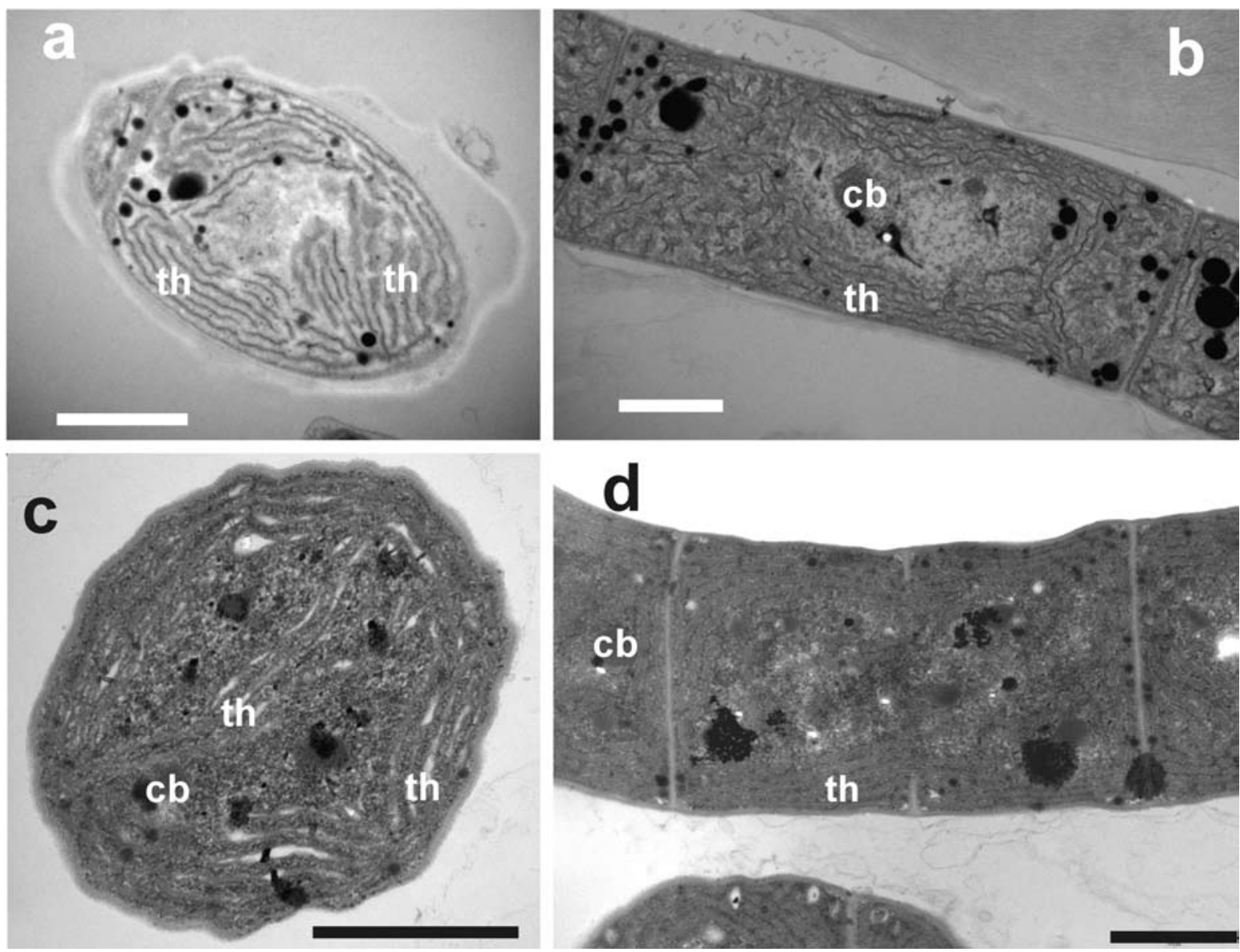

Fig. 5. Ultrastructure of two strains of Wilmottia murrayi: (a-b) strain ANT.ACEV 5.2; (c-d) strain CCALA 843 (type strain). Explanations: (th) thylakoids, (cb) carboxysomes; the agglomeration of cyanophycin and polyphosphate granules near the cross-walls is remarkable (a,b,f). Scale bar $2 \mu \mathrm{m}$. Orig.

generically identical with Wilmottia. They are, e.g., the Antarctic Lyngbya scottii FrITSCH 1912 [= Leptolyngbya scottii (FriTsCH) ANAGNOSTIDIS et KOMÁREK 1988] and (from other regions and other habitats) Phormidium corium Gomont 1892, Ph. crouanii Gomont 1892, Ph. incrustatum GoMONT ex Gomont 1892, Ph. inundatum KützING ex Gomont 1892, Ph. macedonicum ČADO 1959, Ph. papyraceum Gomont ex Gomont 1892, $P h$. rimosum (KoMÁreK) ANAGNostidis et KoMÁreK 1988 and others (cf. ANAGNOSTIDIS \& KOMÁREK 1988).

\section{Acknowledgement}

The study was supported by grants GA ASCR IAA600050704, MSM 6007665801, GACR 206/08/0318 and MŠMT ME 934. The authors thank J.R. Johansen (Cleveland) for the drawing from the original material of Microcoleus glaciei, M. Musílek for laboratory support, L. Kováčik and A. Lukešová for few strains from their collections, A. Wilmotte (Liège) for valuable discussions, J. Šnokhousová and D. Švehlová

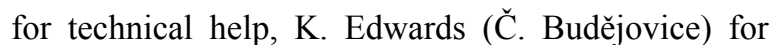
language corrections, and MetaCentrum v.o. for provision of supercomputing facilities under the research intent MSM6383917201. The authors thank also to all colleagues, who helped by any way to this study.

\section{References}

AnAgnostidis, K. \& KomÁreK, J. (1988): Modern approach to the classification system of cyanophytes 3 - Oscillatoriales. - Algological Studies 50-53: 327-472.

Boyer, S.L., Johansen, J.R., Flechtner, V.R. \& Howard, G.L. (2002): Phylogeny and genetic variance in terrestrial Microcoleus (Cyanophyceae) species based on sequence analysis of the 16S rRNA gene and associated 16S-23S ITS region. - J. Phycol. 38: $1222-1235$.

BroAdy, P.A. (2005): The distribution of terrestrial and hydro-terrestrial algal associations at three contrastinc localions in southern Victoria Land, Antarctica. - Algological Studies 118: 95-112. 
Broady, P.A. \& KibBlewhite, A.L. (1991): MorphologicalcharacterizationofOscillatoriales (Cyanobacteria) from Ross-Island and Southern Victoria Land, Antarctica. - Antarctic Sci. 3: 35-45.

Casamatta, D.A., Johansen, J.R., Vis, M.L. \& BroAdwATER, S.T. (2005): Molecular and morphological characterization of ten polar and near-polar strains within the oscillatoriales (cyanobacteria). - J. Phycol. 41: 421-438.

Comte, K., ŠabackÁ, M., Carre-Mlouka, A., Elster, J. \& KomÁReK, J. (2007): Relationships between the Arctic and the Antarctic cyanobacteria; three Phormidium-like strains evaluated by a polyphasic approach. - FEMS Microbiol. Ecol. 59: 366-376.

Elster, J., Lukešová, A., Svoboda, J., Kopecký, J. \& KANDA, H. (1999): Diversity and abundance of soil algae in the polar desert, Sverdrup Pass central Ellesmere Island. - Polar Record 35: 231-254.

Geitler, L. (1932): Cyanophyceae.- In: KolKwitz R. (ed.): Rabenhorst's Kryptogamenflora von Deutschland, Osterreich und der Schweiz, pp.14. - 1196 pp., Akademische Verlagsgesellschaft, Leipzig.

HaLl, T.A. (1999): BioEdit: a user-friendly biological sequence alignment editor and analysis program for Windows 95/98/NT. - Nucl. Acids Symp. Ser. 41: 95-98

Huelsenbeck， J. P. \& RonQuist, F. (2001): MRBAYES: Bayesian inference of phylogeny. -Bioinformatics 17:754-755

Heath, M.W., Wood, S.A. \& Ryan, K.G. (2010): Polyphasic assessment of fresh-water benthic mat-forming cyanobacteria isolated from New Zealand. - FEMS Microb. Ecol. 73: 95-109.

Kатон, K. \& Tон, H. (2010): Parallelization of the MAFFT multiple sequence alignment program. - Bioinformatics 26: 1899-1900.

KomÁreK, J. \& Anagnostidis, K. (2005): Cyanoprokaryota -2. Teil/ 2nd Part: Oscillatoriales. - In: BüDEL B., KRIENITZ L., Gärtner G. \& Schagerl M. (eds), Süsswasserflora von Mitteleuropa 19/2. - 759 pp., Elsevier/Spektrum, Heidelberg.

Lokmer, A. (2007): Polyphasic approach to the taxonomy of the select oscillatorian strains (Cyanobacteria). - 40 pp., Master thesis, Fac. Biol. Sci, Univ. South Bohemia.

MarquardT, J.\& Palinska, K.A. (2007): Genotypic and phenotypic diversity of cyanobacteria assigned to the genus Phormidium (Oscillatoriales) from different habitats and geographical sites. - Arch. Microbiol. 187: 397-413.

Mataloni, G. \& Pose, M. (2001): Non-marine algae from islands near Cierva Point, Antarctic Peninsula. - Cryptogamie Algol. 22: 41-64.
Mataloni, G. \& Tell, G. (2002): Microalgal communities from ornithogenic soils at Cierva Point, Antarctic Peninsula. - Polar Biol. 25: 488-491.

Nübel, U., Garcia-Pichel, F., Muyzer, G. (1997): PCR primers to amplify $16 \mathrm{~S}$ rRNA genes from cyanobacteria. - Appl. Environ. Microbiol. 63: 3327-3332

Palinska, K.A. \& Marquardt, J. (2008): Genotypic and phenotypic analysis of strains assigned to the widespread cyanobacterial morphospecies Phormidium autumnale (Oscillatoriales). Arch. Microbiol. 189: 325-335.

QuesadA, A. \& Vincent, W.F. (1997): Strategies of adaptation by Antarctic cyanobacteria to ultraviolet radiation. - Eur. J. Phycol. 32: 335342.

RipPka, R., Deruelles, J., Waterbury, J.B., Herdman, M. \& STANIER, R.Y.(1979): Generic assignments, strain histories and properties of pure cultures of cyanobacteria. - J. Gen. Microbiol. 111: 1-61.

Š́ABACKÁ, M. (2004): Response of Algal and Cyanobacterial Communities from Arctic and Antarctic Wetland Habitats to Freezing and Desiccation Stress. - 71 pp., Master Thesis, Univ. South Bohemia, Fac. Biol. Sci.

Sambrook, J., Fritsch, E.F. \& Maniatis, T. (1989): Molecular Cloning: a Laboratory Manual 2. 344 pp., Cold Spring Harbor, New York.

SPURR, A.R. (1969): A low viscosity epoxy resin embedding medium for electron microscopy. J. Ultrastruct. Res. 26: 31-43.

Stackebrandt, E. \& Goebel, B.M. (1994): A place for Dna-Dna reassociation and $16 \mathrm{~S}$ ribosomalRNA sequence-analysis in the present species definition in bacteriology. - IJSEM 44: 846849.

Stonehouse, B. (1989): Tertiary Level biology - Polar Ecology. - 222 pp., Blackie, Glasgow.

Strunecký, O., Elster, J. \& KomÁrek, J. (2010a): Phormidium murrayi; endemic cyanobacterium from Antarctica. - In: KOMÁREK, J., HAUER, T. \& KAŠTOvsKÝ, J.(eds): Book of abstracts, $18^{\text {th }}$ Symp. IAC, České Budějovice, p. 90. (Abstract)

Strunecký, O., Elster, J. \& KomÁrek, J. (2010b): Phylogenetic relationships between geographically separate Phormidium cyanobacteria: is there a link between north and south polar regions? - Polar Biol. 33: 14191428.

Tamura, K., Dudley, J., Nei, M. \& Kumar, S. (2007): MEGA4: Molecular Evolutionary Genetics Analysis (MEGA) software version 4.0. - Mol. Biol. Evol. 24:1596-1599.

Taton, A., Grubisic, S., Brambilla, E., De Wit, R. \& Wilmotte, A. (2003): Cyanobacterial diversity in natural and artificial microbial mats of 
Lake Fryxell (Dry Valleys, Antarctica): a morphological and molecular approach. - Appl. Environ. Microbiol. 69: 5157-5169.

Taton, A., Grubisic, S., Balthasart, P., Hodgson, D.A., Laybourn-Parry, J. \& Wilmotte, A. (2006): Biogeographical distribution and ecological ranges of benthic cyanobacteria in East Antarctic lakes. - FEMS Microbiol. Exil. 57: 272-289.

Taton, A., Wilmotte, A., Šmarda, J., Elster, J. \& KomÁreK, J. (2010): Plectolyngbya hodgsonii: a novel filamentous cyanobacterium from Antarctic lakes. - Polar Biol. DOI: 10.1007/ s00300-010-0868-y

Turicchia, S., Ventura, S., KomÁrkovÁ, J. \& KomÁreK, J. (2009): Taxonomic evaluation of cyanobacterial microflora from alkaline marshes of northern Belize. 2. Diversity of oscillatorialean genera. - Nova Hedwigia 89: 165-200.

Yilmaz, M., Philips, E.J. \& Tillett, D. (2009): Improved methods for the isolation of cyanobacterial dna from environmental samples. - J. Phycol. 45: 517-521

West, W. \& West, G.S. (1911): Freshwater Algae in British Antarctic Expedition 1907-09, Biol., part 7, 1: 263-298.
Wilmotte, A., Van der Auwera, G. \& De Wachter, R. (1993): Structure of the 16 S ribosomal RNA of the thermophilic cyanobacterium Chlorogloeopsis HTF (,Mastigocladus laminosus $\mathrm{HTF}^{\circ}$ ) strain PCC7518, and phylogenetic analysis. - FEBS Lett 317:96-100

Wilmotte, A. \& Herdman, M. (2001): Phylogenetic relationships among cyanobacteria based on 16S rRNA sequences. - In: Boone, D.R. \& Castenholz, R.W. (eds): Bergey's Manual of Systematic Bacteriology. - pp. 487-493, Springer, New York.

Wood, S.A., Heath, M.W., Holland, P.T., Munday, R., McGregor, G.B. \& Ryan, K.G. (2010): Identification of a benthic microcystinproducing filamentous cyanobacterium (Oscillatoriales) associated with a dog poisoning in New Zealand. - Toxicon 55: 897-903.

(C) Czech Phycological Society (2011)

Recieved Sept 2010

Accepted Dec 2010 